\title{
PERAN BUKU DAN PERPUSTAKAAN \\ DALAM DEMOKRATISASI INFORMASI
}

\author{
Faisal Syarifudin
}

\begin{abstract}
Democratization of information is a manifestation of a nation's democratic life in which people participate in all aspect of development. Participation requires openness and freedom to get access to information. Availability of information in the global era must be accompanied by competence to filter, process and utilize information, which is known as information literacy. Among various formats of information media, printed materials especially books are mostly preferred because they are easy and convenient to use. Books as information media are closely related to libraries, particularly public libraries which are the most democratic and enable all members of community to interact with information and knowledge. However, it is unfortunate that public libraries and libraries in general have not been given proper attention in Indonesia.
\end{abstract}

Keywords : information literacy, public libraries, public library manifesto

\begin{abstract}
ABSTRAK
Demokratisasi informasi merupakan perwujudan dari kehidupan demokrasi berbangsa yang memberikan pemerataan partisipasi rakyat dalam seluruh aspek. Partisipasi itu membutuhkan keterbukaan dan kebebasan untuk mendapatkan akses informasi. Ketersediaan informasi dalan e ra globalisasi harus diikuti dengan kemampuan untuk menyaring, mengolah dan memanfaatkan informasi dengan baik, yang disebut dengan information literacy. Di antara berbagai macam format media informasi, format tercetak khususnya buku menempati posisi yang paling tinggi karena kemudahan dan kenyamanannya di dalam menggunakan. Buku sebagai media informasi bagi publik tidak terpisahkan dari perpustakaan. Perpustakaan umum adalah perpustakaan yang paling demokratis dan memungkinkan seluruh warga untuk berin teraksi dengan informasi dan pengetahuan. Namun sayangnya di Indonesia perhatian terhadap perpustakaan umum dan perpustakaan secara keseluruhan masih rendah.
\end{abstract}

Kata kunci: information literacy, perpustakaan umum, Public Library Manifesto

\section{DEMOKRASI DAN DEMOKRATISASI INFORMASI}

Demokratisasi adalah derivasi dari istilah demokrasi yang mengandung esensi kedaulatan rakyat. Paham demokrasi meletakkan rakyat sebagai sumber kedaulatan, penyelenggara kedaulatan, dan sekaligus pengawas terhadap pelaksanaan kedaulatan. Samuel Huntington menyoroti ciri-ciri penting yang melekat pada demokrasi, yang memiliki kesamaan yaitu adanya partisipasi rakyat - dalam penentuan para pemimpin mereka, dalam perumusan kebijakan yang berkaitan dengan kepentingan masyarakat, dalam menjalankan kontrol terhadap pelaksanaan kebijakan yang telah disepakati, dan diperlukannya persetujuan rakyat terhadap hasil kebijakan yang dijalankan. Partisipasi rakyat di dalam seluruh proses tersebut dapat terwujud dengan dua syarat. Pertama, kebebasan memperoleh akses informasi, menyampaikan pendapat dan berorganisasi, dan kedua, kesediaan berbagi kekuasaan dengan kelompok-kelompok lain dalam masyarakat. ${ }^{1}$

Dengan demikian demokratisasi merupakan pemberdayaan warga negara dalam seluruh aspek kehidupan barbangsa. Demokratisasi informasi bermakna sebagai hak setiap orang untuk memperoleh informasi, terutama informasi publik. Akses informasi sendiri termasuk hak asasi manusia yang universal. ${ }^{2}$ Pembahasan demokratisasi informasi dalam tulisan ini dibatasi pada seputar pertanyaan "bagaimana peran buku dan perpustakaan sebagai media dan sarana penyebarluasan informasi dan pengetahuan kepada seluruh masyarakat?"

1. ZA Maulani. "Keterbukaan informasi dan stabilitas politik." Dalam Ichlasul Amal \& Armaidy Armawi. Keterbukaan informasi dan ketahanan nasional. Yogyakarta: Gadjah mada University Press. 1996. hlm. 31-32

2. Mirja Ryynanen. "Democrafization of information literacy". Paper pada International Workshp on Democratization of information: focus on libraries. Mumbai, India. 18-19 Januari 2004. Dalam htpp://www.nigd.org/libraries/mumbai/reports/article-10.pdf, diakses 23 Maret 2005 


\section{INFORMATION LITERACY}

Informasi dalam era globalisasi dan keterbukaan masa kini telah dapat diperoleh dimanamana dengan mudah. Namun demikian tidak semua yang sampai kepada kita meru pakan informasi yang bernilai dan bermanfaat, sehingga disyaratkan satu keinampuan menempatkan informasi sesuai konteks dan kebutuhan, yang disebut "information literacy." Istilah information literacy, (Iiterasi atau melek informasi) dalam tulisan ini dikaitkan dengan kedudukan informasi sebagai sumber daya utama dalam kehidupan modern menurut konsep masyarakat informasi. Meskipun informasi itu sesuatu yang intangible (tidak terlihat), tetapi potensi serta urgensinya sangat terasa bagi kehidupan. Informasi dimanfaatkan oleh individu dan organisasi untuk merencanakan, memilih, melaksanakan dan mengevaluasi suatu kegiatan atau tindakan. Pada setiap Iembaga, organisasi, perusahaan dan pemerintah selalu dibentuk suatu divisi yang bertugas sebagai pusat informasi untuk mengumpulkan informasi, menganalisis dan nemberikan masukan kepada manajer sebagai bahan untuk mengambil kebijakan

Bagaimanakah menentukan nilai suatu informasi, sementara informasi itu sendiri adalah fenomena yang unik? Kadang-kadang seseorang kekurangan informasi, tetapi di saat lain kebanjiran informasi sehingga tidak mampu menggunakannya sesuai keperluan. Diperlukan suatu kemampuan yang disebut 'information literacy". Information literacy dimaksudkan sebagai the ability to identify, locate, evaluate, organize, and effectively create, use and communicate information to address an issue or a problem. ${ }^{3}$ Yaitu suatu kemampuan untuk mengolah dan memanfaatkan informasi secara efektif.

Selanjutnya apakah yang dapat dilakukan seseorang yang sudah melek informasi? Ensiklopedia online Wikipedia menyebutkan keahlian-keahlian yang harus dimiliki, yaitu:

1. mengetahui bahwa informasi yang akurat dan lengkap adalah pijakan bagi pengambilan keputusan yang cerdas

2. mengenali kebutuhan akan informasi

3. memformulasikan pertanyaan-pertanyaan berdasarkan kebutuhan informasi
4. mengidentifikasi sumber-sumber informasi yang potensial

5. mengembangkan strategi yang baik dan berhasil dalam mencari informasi

6. memiliki akses kesumber-sumber informasi dengan keahlian teknologi komputer atau teknologi lainnya

7. mengevaluasi informasi

8. mengorganisasi informasi untuk keperluan praktis

9. mengintegrasikan informasi baru ke dalam struktur pengetahuan yang telah dimiliki

10. menggunakan informasi secara kritis untuk memecahkan masalah

Informasi uang baik, menurut Parker harus memenuhi syarat-syarat sebagai berikut:[1] ketersediaan, [2] mudah dipahami, [3] relevan, [4] bermanfaat, [5] tepat waktu, [6] keandaIan, [7] akurat, [8] konsistensi. ${ }^{5}$ Standar ini ditentukan dan dinilai sendiri oleh penggunaya. Dengan kemampuan yang dimiliki seseorang pengguna yang sudah information literate seperti disebutkan di atas, suatu informasi akhirnya menjadi modal yang sangat berharga.

Melek informasi tidak sekedar kemampuan pengguna informasi, namun tidak terlepas pula dari faktor teknologi, kemudahan akses dan kebijakan pemerintah. Mengenai tersedianya informasi, dapat dicermati beragam format media penyebaran informasi (dissemination of information) yang memiliki karakteristik serta kelebihan dan kekurangan masingmasing.

\section{MEDIA PENYEBARAN INFORMASI}

Penyebaran informasi dilakukan melaIui berbagai format media baik cetak yang berbasis kertas maupun elektronik. Media cetak meliputi buku, majalah dan surat kabar, sedangkan media elektronik mencakup siaran televisi, siaran radio dan yang paling actual melalui jaringan internet. Informasi kemudian tidak hanya menjadi komoditas, tetapi penyebarannya juga menciptakan industri dan bisnis penerbitan dan penyiaran. Tulisan ini hanya membicarakan keberadaan buku di tengah kemajuan media informasi. Penemuan mesin cetak oleh Gutenberg dari Jerman merupakan sebuah revolusi yang sangat

\footnotetext{
3. Ibid

4. http://en.wikipedia.org/wiki/Information_literacy, diakses 3 April 2005

5. Charle S. Parker. Management Information System: Strategy and action. Singapore: McGraw Hill. 1989. hlm. 151
} 
mempengaruhi penyebaran informasi. Proses pencetakan yang sudah dikenal di China sejak abad kesembilan memiliki problem karena harus membuat cetakan sebanyak yang dibutuhkan. Gutenberg membuat huruf-huruf yang terpisah dan bias dirangkaikan membentuk kata dan kalimat, dan mendesain mesin yang memungkinkan proses cetak lebih cepat. ${ }^{6}$ Penerbitan bahan cetak menjadi masal dan mudah, maka buku mulai memasuki wilayah bisnis sebagai bahan yang diperdagangkan, terutama pada masa ini dimana teknologi cetak semakin maju dengan memanfaatkan program komputer.

Teknologi informasi sudah membawa masyarakat memasuki era digital. Namun televisi, radio dan teknologi informasi yang maju pesat ternyata tidak menggantikan media cetak terutama buku. Apabila dibandingkan dari segi kenyamanan, buku paling enak digunakan karena hanya membutuhkan cahaya yang cukup, bias dibawa dan dibaca dimana-mana. Sedangkan format elektronik, misalnya CD ROM, e-book dan file di internet memerlukan tempat dan alat untuk membacanya. Teknologi informasi mampu menyajikan informasi dalam format multimedia, sehingga teks dilengkapi image, gambar bergerak, dan suara dapat sekaligus diakses, tetapi harus ada komputer dan listrik untuk menggunakannya.

\section{BUKU SEBAGAI MEDIA PENYEBARAN INFORMASI DAN PENGETAHUAN}

Kandungan sebuah buku bukan sekedar informasi melainkan juga pengetahuan yang dihasilkan melalui pengalainan, pemikiran dan refleksi penulisnya. Sehingga buku dapat dikatakan menjadi media penyebaran ilmu pengetahuan. Untuk mendapatkan informasi, orang cukup mendapatkan berita televisi, radio dan surat kabar. Tetapi tidak ada pelajar, mahasiswa, guru dan dosen yang tidak mengandalkan buku untuk mentransfer pengetahuan. Buku sejenis novel, cerpen dan komik mengandung seni dan hiburan, serta memiliki kekuatan mencerahkan batin, menggugah nurani kemanusiaan, dan merangsang kreativitas.
Tayangan di televisi seperti sinetron menyuguhkan gambar yang dilakonkan menurut penafsiran sutradara terhadap naskah. Penonton harus menerima apa yang dilihatnya tanpa alternatif visualisasi karena gambar-gambar di layar bergerak cepat tanpa ada kesempatan untuk memikirkan dengan tuntas. Sebaliknya buku membuka ruang imajinasi yang tidak terbatas karena pembaca bebas menafsirkan dan memvisualisaikan teks-teks yang tertulis di dalam pikirannya.

Buku dan media-media lain sebenarnya saling mendukung. Di dalam buku ditulis teknikteknik penyiaran radio, cara menelusur di internet dan sebagainya. Sedangkan bahan-bahan yang dimuat di media tersebut diambil pula dari buku. Banyak film, sinetron dan telenovela y ang diangkat dari buku cerita roman, novel dan komik. Demikian juga ada bukubuku yang ditulis berdasarkan skenario film. Promosi buku dilakukan melalui televisi dan radio, bahkan dengan internet jual beli buku menjadi lebih mudah. Sehingga dapat ditegaskan lagi buku tidak tergantikan oleh media lain tetapi saling mengisi kekosongan, memberi inspirasi dan memberi manfaat. ${ }^{7}$ Karena itu setiap saat buku ditulis dan diterbitkan di seluruh dunia.

Melalui buku, sebuah ajaran, ideologi, teori disebarkan secara luas ke masyarakat. Setiap agama didukung dengan buku, kitab suci yang memuat ajaran-ajarannya. Teori-teori besar ditulis dan doperdebatkan di dalam buku, kemudian berpengaruh terhadap kehidupan umat manusia karena dibaca sepanjang masa.

Kehadiran buku tidak terlepas dari dunia penerbitan. Di Indonesia penerbitan buku dalam tahun-tahun terakhir semakin pesat. Untuk Yogyakarta penerbitan berkem bang cukup pesat sejak 1998. Artikel Felicianus \& Ismawan yang datang dari kalangan penerbit menggambarkan keadaan ini. ${ }^{8}$ Mereka mengungkapkan satu alasan mengapa orang berminat menjadi penerbit. Profit margin industri perbukuan relatif besar. Ongkos cetak buku biasanya. $20 \%$ dari harga jualnya. Dengan memperhitungkan rabat $50 \%$ dan royalty penulis $10 \%$ maka penerbit dapat mengantungi keuntungan $20 \%$ dari harga jual buku.

\footnotetext{
6. Putut Widjanarko. Elegi Gutenberg: memposisikan buku di era cyberspace: Mizan, 2000. hal.233

7. Lihat pengantar Hermawan Sulistyo. "Penulis, penerbit, penjual dan pembaca." Dalam Philip G. Albatch \& Damtew Teferra. Bunga rampai penerbitan dan pembangunan. Jakarta: Grasindo, 2000. hal. Xi-xii

8. Julius Felicianus \& Indra Ismawan. Strategi pengembangan usaha penerbitan. Dalam Http:/www.galangpress.com/lihat beritaphp?act $=$ lihat\&idNya=16 16 Agustus 2004, diakses 4 April 2005
} 
Akan tetapi penerbit-penerbit tetap menghadapi masalah. Banyak penerbit kecil yang berdiri namun tidak terdengar lagi setelah menerbitkan beberapa buku. Sebagian besar penerbit masih dikelola dengan sistem manajemen tradisional sehingga banyak aspek yang sulit dikendalikan. Mereka juga menghadapi persoalan hak cipta, hubungan dengan penulis, modal, sistem distribusi, dan pajak.

Masalah serius lainnya adalah pembajakan buku. Kerugian penerbit Indonesia kibat pembajakan sangat besar, bukan hanya hilangnya keuntungan penjualan tetapi berkurangnya kepercayaan dari penulis dan penerbit-penerbit luar negeri. ${ }^{9}$ Apabila kondisi perbukuan semakin buruk maka berakibat menurunnya akses informasi dan pengetahuan secara kualitatif di masyarakat. Orang yang tidak membaca buku akan mengandalkan bahkan menjadi pecandu televisi, yang muatan siarannya sudah diakui lebih bersifat hiburan dan kurang mendidik.

Satu lembaga yang tidak dapat dipisahkan dari buku dan informasi adalah perpustakaan, baik dalam pengertiannya secara umum yang ditekankan pada koleksi buku, maupun pengertian baru yang menitikberatkan kepada fungsinya sebagai pusat dan wahana penyebar informasi.

\section{PERAN PERPUSTAKAAN DALAM DEMOKRATISASI INFORMASI DAN PENGETAHUAN}

Dari sisi ketersediaan media informasi, buku dan media cetak lainnya sangat banyak ditemukan di toko-toko buku, sehingga pada saat orang ingin mengetahui dan mempelajari sesuatu hal ia sebenarnya dapat membeli buku atau majalah yang sesuai. Di kota-kota hampir selalu terdapat toko yang menjual buku. Akan tetapi perhatian dan daya beli masyarakat terbatas dan biasanya diprioritaskan untuk memenuhi kebutuhan yang lebih penting. Makanan dan pakaian harus terlebih dahulu dicukupi di dalam kehidupan sehari-hari, sehingga biaya untuk membeli buku disisihkan sesudahnya. Tempat alternatif mendapatkan bacaan dengan murah bahkan tanpa biaya adalah perpustakaan.
Tradisi membaca dan menulis yang sudah berakar dalam masyarakat menjadi fondasi yang kokoh bagi keberadaan perpustakaan, sehingga perpustakaan mempunyai sejarah panjang di Eropa dan Amerika khususnya perpustakaan umum, dan mendapat perhatian dari pemerintah serta seluruh rakyat. Penguasa pertama yang mendukung penyelenggaraan perpustakaan umum adalah Emperor Augustus dari Roma. Ia meneruskan ide pendahulunya Julius Caesar yang terbunuh sebelum mewujudkan rencananya membangun perpustakaan. Perpustakaan umum pertama dibangun di biara Apollo di atas bukit Palatine pada tahun 28 SM.

Memberikan perhatian terhadap perpustakaan bukanlah hal yang sulit mengingat kebudayaan-kebudayaan awal telah mendokumentasikan sejarah mereka dalam clay tablet, gulungan papirus dan kertas perkamen. Koleksikoleksi yang penting terpelihara dengan baik, misalnya di perpustakaan Alexandria Mesir yang sudah berdiri sesudah 350 SM. Di Amerika Serikat, menjelang akhir abad ke-17 sudah dilakukan suatu sistem peminjaman buku kepada warga terutama jemaah gereja yang merupakan embrio perpustakaan umum. Setiap masa, tokoh-tokoh politik, pengusaha dan masyarakat menyumbangkan tidak hanya ide, melainkan juga koleksi dan dana untuk perpustakaan. ${ }^{10}$

Di kalangan dunia Islam, buku dan perpustakaan sudah menjadi peradaban sejak munculnya sarjana-sarjana Islam periode awal meskipun baru terbatas pada kertas-kertas catatan koleksi pribadi. Pada masa-masa berikutnya berdiri perpustakaan-perpustakaan yang dibiayai oleh negara, dan termasyhur adalah Baitul Hikmah yang didirikan oleh Khalifah Harun Al Rasyid di Baghdad pada tahun $830 .{ }^{n}$ Etos menuntut ilmu sesungguhnya telah ditumbuhkan di dalam ajaran agama. Ayat-ayat yang diturunkan pertama kali kepada Nabi adalah perintah untuk membaca.

Di Indonesia, sejarah perpustakaan yang dikelola sebagai sebuah lembaga hanya dapat dirunut ke masa penjajahan Belanda, yang mendirikannya untuk kepentingan penelitian-penelitian dan memajukan pendidikan bagi orang Belanda yang bekerja di Indonesia. Secara singkat mengenai

9. Misalnya baca berita Republika 4 April 2005 hal.3 tentan penangkapan pembajak buku dan penjual buku bajakan di Jakarta 10. Whitney North Seymour \& Elizabeth Layne. For the people: fighting for public libraries. New York: Doubleday, 1979. hlm. 4-11 11. Zainuddin Sardar. Peradaban buku. Dalam merombak pola pikir intelektual muslim. Zianuddin Sardar (ed) Yogyakarta: Pustaka Pelajar, 2000 
perpustakaan di Indonesia dikemukakan di bawah ini:

1. Perpustakaan NasionaI.

Perpusnas adalah lembaga pemerintah nondepartemen (LNDP), yang secara langsung bertanggungajawab kepada presiden. Perpusnas lahir 17 Mei 1980 sebagai UPT di Dekdipbud dibawah koordinasi Dirjen Kebudayaan. Tanggal 16 Maret 1989 Perpusnas berubah sebagai LNDP dengan Keppres No. 11 tahun 1989 dan disempurnakan dengan Keppres No. 50 tahun 1997.

\section{Perpustakaan Daerah.}

Pada awal kelahirannya disebut Perpustakaan Negara, berada di ibukota propinsi sebagai UPT di Depdikbud. Yang pertama berdiri adalah Perpustakaan Negara Yogyakarta tahun 1949, Semarang 1951, Ambon 1952. Di kota-kota yang lain di Indonesia menyusul pada perkembangan berikutnya. Kemudian disempurnakan menjadi Perpustakaan Wilayah dengan Kepmen Pendidikan, Pengajaran dan Kebudayaan (PPK) No. 0199 tahun 1978, yang berarti masih dibawah Depdikbud sebagai UPT. Dengan Keppres No. 11 tahun 1989 menjadi Perpustakaan Daerah dibawah Perpusnas, dan disempurnakan melalui Keppres No. 50 tahun 1997. Dengan berlakunya otonomi daerah, perpustakaan ini terlepas dari Perpusnas dan menjadi bagian dari pemerintah propinsi.

\section{Perpustakaan Umum.}

Perpustakaan umum (dulu Perpustakaan Rakyat) dibentuk berdasarkan Surat Putusan Menteri PPK No. 7870 tahun 1953. Kemudian keluar Kepmendagri No. 9 tahun 1988, ditindaklanjuti dengan Instruksi Mendagri No. 21 tahun 1988. Kedudukan perpustakaan umum adalah sebagai UPTD P\&K. Selanjutnya dengan Kepmendagri No. 56 tahun 1994 Perpustakaan
Umum Daerah Tingkat II menjadi Unit Pelaksana Daerah yang bertanggungjawab langsung kepada kepala daerah tingkat II. Kepmendagri tersebut diikuti dengan Instruksi Mendagri No. 9 tahun 1996. ${ }^{12}$ Kedudukan ini berlaku sampai masa otonomi daerah saat ini.

\section{BAGAIMANAKAH PERPUSTAKAAN BERPERAN DALAM PROSES DEMOKRATISASI INFORMASI?}

Perpustakaan umum merupakan satu model demokratisasi informasi dan pengetahuan yang paling tepat karena perpustakaan umum adalah tempat yang terbuka untuk seluruh anggota masyarakat, tidak ada batasan bagi mereka untuk mengakses perpustakaan. Jenis-jenis perpustakaan Iain layanan atau keanggotaannya terbatas. Perpustakaan nasional tidak meminjamkan buku, perpustakaan sekolah dan perguruan tinggi tidak melayani masyarakat umum. Sedangkan perpustakaan umum harus melayani kepentingan umum karena didirikan dengan biaya yang berasal dari masyarakat.

Pada tahun 1972 dan tahun 1994 UNESCO mengeIuarkan Manifesto Perpustakaan Umum ${ }^{13}$ yang menekankan bahwa perpustakaan umum harus menyediakan semua jenis informasi bagi pengguna, layanannya didasarkan atas persamaan hak akses untuk semua, tanpa membedakan ras, usia, agama, kebangsaan, bahasa atau status social. Koleksi dan pelayanan perpustakaan tidak boleh menekankan pada bentuk ideologi, politik dan agama tertentu atau bersifat komersial.

Menurut manifesto UNESCO, tujuan prinsipil dari perpustakaan umum adalah:

1. menciptakan dan memperkuat kebiasaan membaca pada anak-anak

2. mendukung pendidikan

3. merangsang kreativitas dan imajinasi kaum muda

4. membangkitkan kesadaran akan warisan budaya

5. menjamin ketersediaan akses informasi

12. Supriyanto. Prospek Perpustakaan Indonesia masa depan. Dalam Supriyanto. Et.al (ed). Kepustakawanan Indonesia dan sumbangannya kepada masyarakat. Semarang: Perpustakaan Unika Soegijapranata, 1998. hal. 78-80.

13. UNESCO. UNESCO Public Library Manifesto http://www.unesco.org/webworld/libraries/manifestos/ libraman.html diakses 12 Februari 2005

14. Fuad Hasan. Perpustakaan sebagai Pusat Pembelajaran dan Agen Perubahan. Download dari http:// www.hamline.edu/apakabar/basisdata/2001/08/14/0120.html diakses 12 Februari 2005 
Dari pernyataan diatas, jelas dipahami perpustakaan mengemban tugas sebagai agen perubahan sosial, memperbaiki mutu kehidupan masyarakat. Menurut Fuad Hasan ${ }^{14}$, tindakan untuk mengatasi ketertinggalan masyarakat biasanya dimulai dengan upaya meningkatkan kecerdasannya. Ia menyebutkan tiga faktor utama penyebab ketertinggalan suatu masyarakat, yaitu: ketidaktahuan, kemiskinan, dan penyakit (ignorance, poverty and disease) yang berkaitan erat satu sama lain.

Dalam usaha untuk menanggulanginya biasanya diu tamakan berbagai ikhtiar yang ditujukan pada teratasinya faktor ketidaktahuan, seperti antara lain program pemberantasan buta huruf, disusul dengan penyelenggaraan sekolah-sekolah dan kursuskursus. Berbagai ikhtiar tersebut ditujukan pada meningkatnya penguasaan pengetahuan dan ketrampilan masyarakat sehingga terbuka pemikirannya mengenai bahan bacaan yang dapat membimbing individu dalam mengembangkan bakat dan minatnya masing-masing, maka setiap orang dapat menambah pengetahuannya, yang berarti semakin cerdas.

Fuad Hasan menekankan kehadiran perpustakaan dalam suatu lingkungan masyarakat niscaya turut berpengaruh terhadap teratasinya kondisi ketertinggalan masyarakat yang bersangkutan. Tentu saja hal ini baru dapat diakui apabila perpustakaan mampu menyediakan bahanbahan bacaan yang sesuai dengan kebutuhan masyarakat tersebut, fasilitas dan pelayanan yang baik pula.

Bila diperhatikan Indeks Pembanguan Manusia (Human Development Index) yang dilaporkan oleh Program Pembangunan Perserikatan BangsaBangsa (United Nations Development Program 2003) Indonesia berada pada peringkat ke 112 dari 175 negara, tertinggal dari negara tetangga seperti Singapura (28), Brunei (31), Malaysia (58), Thailand (74), Filipina (85), dan Vietnam (109). Ini menunjukkan bahwa standar kualitas hidup bangsa Indonesia lebih rendah dari bangsa-bangsa lain di Asia. ${ }^{15}$ Keadaan ini memang mungkin disebabkan oleh tiga faktor seperti disebutkan Fuad Hasan, dan upaya mengatasinya dimulai dengan menghilangkan ignorance, yang dilakukan melalui pendidikan, pemberian informasi dan melalui bahan-bahan bacaan. Di dalam hal inilah perpustakaan dapat menjalankan peranannya.

Pada bagian berikut ini pembahasan difokuskan pada pengelolaan perpustakaan umum di Kota Yogyakarta. Penulis pernah melakukan penelitian kecil tentang pengelolaan perpustakaan umum Kota Yogyakarta. Mengingat keberadaan Kota Yogyakarta sebagai daerah tujuan wisata, kota budaya dan kota pendidikan, dengan jumlah penduduk lebih dari 511 ribujiwa, dimana banyak kampus perguruan tinggi berada. ${ }^{16}$ Perpustakaan seharusnya dapat memainkan peran penting dalam meningkatkan budaya masyarakat membaca dan belajar dengan menyediakan bacaan yang baik dan menarik. Disamping itu perpustakaan menjalankan peran melestarikan dan memperkenalkan budaya daerah, mempromosikan potensi daerah dan kebijakan pemerintah.

Perpustakaan Kota Yogyakarta berdiri tanggal 2 Mei 1993 sebagai UPTD pada cabang Dinas P\&K. Ketentuan terbaru tentang perpustakaan ini adalah Perda No. 22 tahun 2000 tentang Pembentukan, Susunan Organisasi dan Tata Kerja Dinas Pendidikan dan Pengajaran, kemudian lebih jauh diatur dalam SK Walikota No. 70 tahun 2001 tentang Rincian Tugas pada Dinas Pendidikan dan Pengajaran Kota Yogyakarta. Perda No. 22 tahun 2000 pasal 37 menyebutkan UPT Dinas P\&P terdiri dari UPTD Sanggar Kegiatan Belajar (SKB) dan UPTD Perpustakaan Umum Daerah. Tugas UPTD Perpustakaan ditentukan dalam SK Walikota No. 70 tahun 2001 pasal 30.

Perpustakaan menempati kantor di Jalan Pekapalan, berdampingan dengan gedung Museum Sonobudoyo diatas tanah milik Kraton Yogyakarta. Lokasi ini sampai sekarang masih bertahan dan sebenarnya sangat strategis karena barada sangat dekat dengan Alun-alun Selatan, dan Kraton Yogyakarta serta tidak jauh dari Jl. Malioboro. Sekitar kawasan tersebut setiap hari ramai dikunjungi masyarakat yang merupakan pengunjung potensial perpustakaan, hanya saja jumlah kunjungan masih sangat minim, rata-rata 15 orang per hari.

Tenaga yang mengelola perpustakaan berjumlah 8 orang. Keseluruhan pengelola

15. Yayasan bangun Indonesia. http://www.watershedpress.com/bif.3maret04html, diakses 12 Februari 2005

16. Badan Kependudukan Keluarga Berencana dan catatan Sipil Kota Yogyakarta. Laporan Kependudukan. Per Juli 2004 jumlah penduduk 511.744 jiwa. Dikutip dari website www.jogja.go.id 12 Februari 2005. Perguruan Tinggi di Yogyakarta (DIY) 135 buah terdiri atas 4 PTN, 6 PT Kedinasan, 125 PTS. Lihat Ananta Heri Pramono. "Mempertahankan Jogja sebagai pusat pendidikan berkualitas. "Artikel dalam Buku panduan Pesta Buku logja 2005. hal. 9. 
perpustakaan tidak memiliki jabatan fungsional pustakawan, bahkan seorang staf yang sebelumnya adalah pustakawan di sebuah SMU kemudian tidak memiliki jabatan fungsional lagi. Perpustakaan dipimpin oleh seorang Kepala yang membawahi para staf. Selanjutnya belum dibentuk jabatan-jabatan di dalam organisasinya mengingat koleksi, layanan dan tempat yang masih terbatas. Namun untuk kegiatan operasional yaitu pengolahan koleksi dan pelayanan pemakai tetap diberikan tanggungjawab kepada staf tertentu.

Koleksi yang tersimpan di perpustakaan terdiri atas buku, laporan hasil penelitian, skripsi mahasiswa yang lokasi penelitiannya di Kota Yogyakarta, dan terbitan-terbitan pemerintah. Semuanya berjumlah 2712 judul, 3519 eksemplar meliputi bidang-bidang umum serta agama. Perkem bangan koleksi berawal dari pengadaan oleh Dinas Pendidikan, sumbangan dari perpustakaan daerah tingkat I dan sumbangan dari masyarakat.

Untuk membiayai kegia tannya, setiap tahun perpustakaan mengajukan anggaran kepada Kepala Dinas P\&P, namun yang diterima selalu dibawah jumlah yang diajukan, misalnya untuk tahun 2004 perpustakaan mendapat 4 juta rupiah dalam bentuk buku untuk koleksi. Minimnya biaya membuat kondisi perpustakaan masih sederhana dan koleksi tidak bertambah dengan cepat, tidak seiring dengan banyaknya buku yang terbit setiap tahun serta perkembangan media informasi.

Lokasi perpustakaan di kawasan yang strategis tidak didukung dengan sarana bangunan yang lengkap dan nyaman. Di perpustakaan hanya tersedia ruangan yang kurang luas dan sedikit meja untuk membaca. Penambahan bangunan tidak mungkin dilakukan karena lahannya sempit serta tanah yang ditempati adalah milik Kraton.

Dari gambaran diatas, bisa dipahami bahwa Pemerintah Kota belum memiliki komitmen yang tinggi untuk mengembangkan perpustakaan umum. Secara struktural kelembagaan, kedudukan perpustakaan umum tidak mengalami perubahan dari masa sebelum dan sesudah penerapan otonomi daerah, yaitu tetap menjadi UPT dibawah Dinas Pendidikan. Kedudukan demikian membawa konsekuensi dari segi wewenang dan dana. Perpustakaan hanya menjadi pelaksana saja, menyusun daftar buku, melakukan pengolahan dan pelayanan. Untuk pustakawan tidak diatur jabatan dan tunjangan fungsional, serta anggaran yang disediakan masih sangat minim.

Sebagai perbandingan mengenai perhatian pemerintah daerah dapat dilihat Kabupaten Bantul, perpustakaannya memiliki koleksi lebih dari 15.000 buku, didukung 4 mobil keliling untuk menjangkau desa-desa. Perpustakaan juga bekerjasama dengan Kantor Pengolahan Data Elektronik dan Warintek membuka layanan internet bagi masyarakat. Mereka berhasil meraih penghargaan tingkat nasional "Citra Layanan Prima" dari Presiden Megawati Sukarnoputri pada September 2004. Perpustakaan Umum Kota Yogyakarta juga belum didukung dengan promosi kepada masyarakat. Misalnya di website Pemkot (http://www.jogja.go.id) pada informasi fasilitas kota hanya ada 3 perpustakaan yang dimuat (Perpustakaan Islam Badan Wakaf, Taman Bacaan Titin dan Taman Pustaka Kristen), sedangkan Perpustakaan Umum milik Pemkot sendiri tidak ditampilkan.

Beberapa poin diatas memberikan gambaran bahwa kedudukan Perpustakaan Umum Kota Yogyakarta sebagai UPT Dinas P\&P tidak mengalami perubahan sejak masa sebelum dan sesudah penerapan otonomi daerah. Perhatian pemerintah kota masih sangat rendah, tercermin dalam kebijakan yang mengatur struktur kelembagaan, anggaran dan saran yang diberikan kepada perpustakaan. Sebagai konsekuensinya perpustakaan belum dapat menjalankan perannya untuk menyediakan akses informasi dan menjadi pusat sumber belajar bagi masya rakat secara maksimal. Otonomi daerah ternyata juga tidak membawa kemajuan berarti bagi SDM perpustakaan dimana pustakawan belum diakui sebagai jabatan fungsional.

\section{PENUTUP}

Buku dan perpustakaan memegang peranan penting di dalam proses demokratisasi informasi, bahkan dalam penyebaran pengetahuan. Kehadiran beragam format media penyebaran informasi yang didukung oleh kemajuan teknologi informasi tidak dapat menggantikan buku sebagai media yang paling mudah digunakan.

Perpustakaan umum adalah salah satu lembaga yang paling demokratis yang dapat diakses oleh seluruh lapisan masyarakat, sehingga sejak 30 tahun yang lalu PBB mengeluarkan Public Library Manifesto. Perpustakaan umum telah menjalankan fungsinya dengan baik karena mendapat perhatian yang besar dari pemerintah dan dukungan masyarakat. Hal ini terjadi di luar Indonesia, terutama di negara-negara maju, sementara di Indonesia pada umumnya perhatian terhadap perpustakaan masih kurang. 


\section{DAFTAR PUSTAKA}

Badan Kependudukan Keluarga Berencana dan Catatan Sipil Kota Yogyakarta. Laporan Kependudukan. Dalam www.jogja.go.id, diakses 12 Februari 2005.

Felicianus, Julius, Indra Ismawan. Strategi pengembangan usaha penerbitan., Dalam http:www.galangpress.com/ lihat berita.php?act $=$ lihat\&idNya $=16$, diakses 4 April 2005

Hasan, Fuad. Perpustakaan sebagai Pusat Pembelajaran dan Agen Perubahan. Didownload dari http:// www.hamline.edu/apakabar/basisdata/2001/ 08/14/0120.html, diakses 12 Februari 2005. http://en.wikipedia.org/wiki/ Information literacy diakses 3 April 2005

Maulani, ZA. "Keterbukaan informasi dan stabilitas politik." Dalam Ichlasul Amal \& Armaidy Armawi. Keterbukaan informasi dan ketahanan nasional. Yogyakarta: Gadjah Mada University Press, 1996.

Parker, Charles S. Management Information Systems : Strategy and Action. Singapore:McGraw-Hill, 1989.

Pramono, Ananta Heri. Mempertahankan Jogja sebagai pusat pendidikan berkualitas. Artikel dalam buku panduan Pesta Buku Jogja 2005. Republika, 4 April 2005; hal. 3

Ryynanen, Mirja. "Democratization of information: information literacy." Paper presented at International Workshop on Democratization of information: focus on libraries. Mumbai, India; 1819 Januari 2004. Dalam http://www.nigd.org/ libraries/mumbai/reports/ article-10.pdf, diakses 23 Maret 2005.

Sardar, Ziauddin. "Peradaban buku." Dalam Merombak pola pikir intelektual muslim. Ziauddin Sardar (ed.). Yogyakarta: Pustaka Pelajar, 2000.

Seymour, Whitney North, Elizabeth Layne. For the people: fighting for public libraries. New York: Doubleday, 1979.

Sulistyo, Hermawan. "Penulis, penerbit, penjual dan pembaca." Dalam Philip G. Albatch \& Dam tew Teferra. Bunga rampai penerbitan dan pembangunan. Jakarta: Grasindo, 2000.

Supriyanto. "Prospek perpustakaan Indonesia masa depan." Dalam Supriyanto et al (ed.) Kepustakawainan Indonesia dan sumbangannya kepada masyarakat. Semarang: Perpustakaan Unika Soegijapranata, 1998; hal. 78-80.

UNESCO. UNESCO Public Library Manifesto. Dalam http://www.unesco.org/webworld/libraries/ manifestos/libraman.html, diakses 12 Februari 2005.

Widjanarko, Putut. Elegi Gutenberg: memposisikan buku di era cyberspace. Bandung: Mizan. 2000.

Yayasan Bangun Indonesia. http:// www.pertiwi.co.id/yayasan/index3.html, diakses 12 Februari 2005. 